\title{
Religious Aspects of Psychedelic Drugs
}

\author{
Walter Houston Clark*
}

Even so, this organ of knowledge must be turned around from the world of becoming together with the entire soul, like the scene shifting periact in the theater, until the soul is able to endure the contemplation of essence and the brightest region of being.

$$
\text { -Plato }
$$

0 NE ASPECT of the very controversial "hallucinogenic" or "psychedelic" drugs is whether they generate religious experience, and if so, whether this experience is genuinely religious. This Article examines the available evidence that psychedelic drugs do induce religious experience in hopes that its conclusions might promote rational consideration of legal issues surrounding drugs.

Before considering the rehgious potential of psychedehic drugs, however, one must supply a working definition of "religion." Further, to identify the characteristics of a profoundly religious experience we shall study several historical figures to indicate how a person undergoing sucl an experience may be expected to feel and act.

\section{$I$}

\section{THE DEFINITION OF RELIGION}

Defining religion is difficult because each individual defines it to suit himself, his purposes, and perhaps his prejudices. I once circulated a questionnaire among social scientists interested in religion-a group who might be expected to supply definitions with some rigor-asking them to define religion. No two agreed, and their definitions ranged from perception of the supernatural to loyalty to institutions and creeds. ${ }^{1}$ Webster's New International Dictionary hists nine definitions. It is obvious that each defimition reflects, at least to some degree, that aspect of religion under study -in this case, religion as experienced. It is experiential religion that is claimed to accompany ingestion of psycliedelic drugs.

The dictionary definition of religion closest to this purpose reads in part, "An apprehension, awareness, or conviction of the existence of a supreme being, or more widely, of supernatural powers or influences controlling one's own, liumanity's or nature's destiny; also, such an appre-

* A.B., 1925, Williams College; M.A., 1926, Ed.M., 1935, Ph.D., 1944, Harvard University; Visiting Professor of Psychology of Religion, Tufts University; Andover Newton Theological School, Retired. (1958).

1 Clark, How do Social Scientists Define Religion? 47 J. Socrax Psycrology 47, 143-47 
hension, etc., accompanied by or arousing reverence, love, gratitude, the will to obey and serve, and the like; religious experience or insight ...."2 This definition approaches my own. I see religion as the inner individual's experience of a Beyond, especially as evidenced by his attempts to harmonize his life with the Beyond. These definitions indicate that religion may be an individual affair presupposing neither church nor religious institution.

\section{II}

\section{RELIGIOUS EXPERIENCE AND THE LAW}

One salient characteristic of intense religious experience is its tendency to create within the beholder deeply held convictions which cause hini to place religious considerations above all others. Those unsympathetic with such convictions may find them to be mere fanaticism or lunacy, which may in fact sonietimes be the case. But it is difficult for contemporaries, without the benefit of history, to determine the wholesonjeness of belief and behavior. Many of the world's great religious figures were once considered criminal, mad or both. Moses was a fugitive; the early Clristians were accused of "Iratred of the human race"; the religious integrity of George Fox sent him to prison many times; and Martin Luther was forced to maintain his integrity in the shadow of martyrdom. Contemporary America has confronted conscientious objectors whose religious convictions impell then to resist the draft and has watched the Amish sell their ancestral lands rather than compromise their religious convictions by sending their children to state approved schools.

In such cases the position of the law supported by contemporary public opinion finds echo in a Second Century document concerning Christians written by Phny, Ronian Governor of Bithynia, to his master, the emperor Trajan. Pliny gave those culprits who confessed Christianity a chance to recant. "Those who persisted I ordered to be executed, for I did not doubt that whatever it was they professed they deserved to be punisled for their inflexible obstinacy."

\section{A. The Mystical Experience}

This lack of understanding and failure of communication is compounded when the offense involves mystical religion-according to William Janies the "root and centre" of personal religious experience." The mystical state of mind as it has appeared througliout time has been most

2 Webster's Second NeW INTERNATtoNaI Dictionary, UNABRTDGED 2105 (1950).

3 Quoted in R. Bannton, The Horzzon History of Christianttiy 66 (1964).

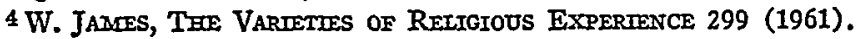


perceptively studied by W. T. Stace of Princeton University. ${ }^{5}$ Contrary to much educated though ill-informed opinion, mysticism is neither superstition nor vague emotion but, at least in its essential characteristics, an identifiable state of mind, probably the most intense and captivating of which human nature is capable. In the seventh book of The Republic Plato describes it as "the brightest region of being." At its core is a perception of the world so different from what is usually called reality that mystics universally failed in conveying its nature to those who have not enjoyed some measure of mystical perception themselves. The annals of mysticism reveal that mystics perceive a simple and yet marvelous unity underlying the appearance of all hing things and matter. From this derives the compassion, empathy, and understanding so often developed as a prime fruit of the mystic's consciousness. The mystic also feels himself in touch with the Holy and Divine-that objective, ultimate reality beyond time and space that brings with it the "peace that passes understanding," yet which can be described to nonmystics only through paradox and riddles. Hence, the niystic is the artist and poet of the religious life. To ask the mystic to renounce his perception or to eschew behavior contingent on it is therefore tantaniount to asking him to deny himself. The mystic's position is like that of a seeing man in a society of the blind. How would lie justify his experience of sight? His stammering attempts to convey to the blind his experience of sight would only mark him as peculiar; and his adventures into the world based on a sense of sight would only appear as the sheerest madness and probably as a threat to the society. Plato tries to make this point in the seventh book of The Republic through his famous analogy of the Cave, ${ }^{7}$ a passage containing special significance for any mystic who delightedly comes upon it.

\section{B. Historical Persecutions of Mystics}

\section{The Trial of Socrates}

Because the mystic faces an inevitable struggle in sharing a truth which he may feel is "death to hide," Plato emphasizes his need for courage. Plato derived this conviction from perhaps history's most notable encounter between a mystic and the law-the trial and execution of Socrates. The jury was the total Athenian electorate. Speeches were made by the accused, his accusers, and his defenders according to clear rules

5 See W. Stace, Mysticism and Phmosophy ch. 2 (1960). For a review of the various forms of mysticism, see W. CiARK, The Psychology of Retigion ch. 12 (1958). See also the writing of A. H. Maslow describing what he terms "peak-experiences," e.g., Retrorous VALUES, AND PEAK-EXXPERENCES (1964).

${ }^{6}$ W. Clark, Three Thousand Years of Educational Wisdom 49 (R. Ulich ed. 1954).

7Id. at $46-50$. 
of procedure. Socrates stood accused of corrupting the youth of Athens. Some of the fruits of this "corruption" appear in the writings of Plato, who became a disciple of Socrates. In his dialogues, Plato ascribes to Socrates many statements of a mystical nature, as in the allegory of the Cave. One can imagine that the people of Athens who acted as a collective jury at his trial unconsciously convicted Socrates as much for his mysticism as for anything. The tragedy of Socrates' execution was not the failure of a good judicial system or the failure of democracy, for both operated consistently according to their own rules. The tragedy was the failure of the solid citizens to communicate with the younger generation-the rebels and the hippies of their day-whose leader, Socrates, became the scapegoat for contemporary civic frustrations. Condemned to death by his contemporaries, Socrates, the mystic, was unable to convey his vision to those who were imprisoned in the Cave of delusion that caused them to regard anyone with a wider vision as a madman and a menace. $^{8}$

\section{Mystics and the Law during the Middle Ages}

This same breakdown of communication between the accused and their judges occurred during the Middle Ages. Though some victims executed were doubtless evil characters who deserved their pumishments, others were sensitive mystics guilty only of communicating their visions and experiences in terms which antagonized their iheological judges. Ecclesiastical law, the most influential law of the time, considered heresy the most heinous of offenses, for, although it did not kill the body, it led the soul into everlasting damnation. But heresy was not always easy to detect; its determination sometimes took years of theological consideration. And often, as in the case of Socrates, the determination reflected a breakdown of communication since the theologians, though experts in ecclesiastical law, frequently had no intuitive or psychological understanding of the mystic's essential religious experience.

A case in point is that of Meister Eckhart, the great German Dominican mystic of the 13th and 14th centuries. Much bolder than some of his more docile followers who escaped condemnation, he interpreted theology in his writings and sermons directly and immediately from his own encounters with reality. Modern studies have discovered that his writings reflect the mystical consciousness with subtlety and precision. ${ }^{9}$ Yet the necessities of dogma demanded censure in the eyes of the ecclesiastical courts.

8 See A. E. TAYLor, Socrates (1953) for an account of the trial and the role of Socrates' personality.

9 See, e.g., W. STACE, supra note 5. 
Eckhart's theological crime was pantheism-equating God with all of the natural world and identifying oneself with this Whole, as did the great Enghish poet, William Blake. Theoretically mysticism leads to confusing oneself with God and therefore to delusions of grandeur and theological arrogance. Eckhart often spoke of identity with God as a Christian virtue: "If I am to know God directly, I must become completely $\mathrm{He}$ and $\mathrm{He} \mathrm{I}$; so that this $\mathrm{He}$ and this I become and are one I."10 Fortunately Eckhart was a well-known preacher and influential ecclesiastic. Hence it was not until two years after his death that he was finally declared heretical and so saved from the flames that, as with Jeanne d'Arc, might well have been his lot. Nevertheless his judges lacked that keenness of spiritual consciousness that would have enabled them to identify Eckhart with some of the greatest Fathers of the Church and his religious experience with the piety to which centuries of Christian opinion had paid verbal homage.

Yet another witness to the mystical experience was the more docile and orthodox Blessed Angela of Foligno, an influential thirteenth century Itakian mystic. When she was informed that her charity and consequent poverty were too radical, she cried, "Lord, even if I am damned, I will nevertheless do penance and will strip myself of everything and serve Thee!"11 This attitude emphasizes the passion and the conviction of even the more conventional mystics.

\section{Mysticism and Freedom of Religion}

The confrontations which occur when the mystic's intense feeling collides with the judge's lack of experience lead at best to impass and at worst to tragic miscarriages of justice. A mystic like the Blessed Angela who can show such independence in the face of God would probably also defy an earthly judge who required her to desist from certain religious activities. This kind of passion has doubtless imfluenced Western peoples, so far as possible, to respect the religious ways of deeply convinced religious partisans. To harass a patently sincere person for pursuing a profound rehigious leading not only offends religious sensitivities, but also causes civil disturbance. In part this explains the development of religious freedom.

\section{III}

PSYCHEDELIC DRUGS AND RELIGIOUS EXPERIENCE

The history of mysticism provides a background for assessing the religious potential of psychedelic drugs. We understand cases like those

10 Quoted in E. UNDERHIII, MYSTICTSM 420 (1955).

11 Quoted in W. CLARK, supra note 5, at 288. 
of Socrates and Eckhart involving historical episodes about which we have had time to make up our minds. Because history never exactly repeats itself, it would be specious to argue with particularity from Socrates and Eckhart to the prosecution of contemporary psychedelic mystics. But there are close parallels worth considering-perhaps too close for us to feel completely comfortable about restrictive narcotics legislation.

Before reaching conclusions on these problems, it will be necessary to determine whether psychedehics in fact release profound mystical or other religious experiences. If so, religious groups and even individuals may be constitutionally protected in using psychedelic drugs in the pursuit of religious aims.

\section{A. Psychedelic Drugs Help Induce Religious Experiences}

I have already indicated my conviction that mystical experience is at the heart of the religious life. It is significant that religious experience so often has been reported in connection with the psychedelic drugs. The ingestion of a psychedelic drug will not invariably touch off a mystical experience. Therefore, we cannot think of the psychedelics as the cause of religious experience. It is true that a mystical experience is more bikely to occur the larger the dosage of the drug taken. But the participant's intention, his personality, and the setting in which he ingests the drug all play a part in the production of a religious experience. Probably the primary and necessary cause of mystical experience is the inystical capacity residing within the person himself. Whether all have this capacity is a matter of dispute; but probably, like the capacity to experience beauty, it is present in everyone to some degree. Some simply are Inore apt to have mystical perceptions than others. Psychedelic drugs, in common with sucl stimuli as scenes of natural beauty, childbirth, the dance, music, poetry, liturgical splendor, and the presence of other mystically sensitive people, will trigger mystical experience. Furthermore they constitute the most reliable triggers that we have. Millions of Americans, if they are ever to enjoy profound religious experience, will only do so througl psycliedelic drugs. I have been persuaded of this quality of psychedehc drugs inainly by one well-desigued experiment at Harvard University. Dr. Walter N. Pahnke, who has umversity degrees in both medicine and rehgion, obtamed twenty theological students as volunteers. ${ }^{12}$ After suitable preparation, ten were given $30 \mathrm{mg}$. of psilocybin

12 Drugs and Mysticism: An Analysis of the Relationship betreen Psychedelic Drugs and the Mystical Conscionsness, Doctoral dissertation, Harvard University, 1963. A summary of the same experiment may be found in THE USE OF LSD IN PSTcHotherapy AND AICOHolisMr 629-49 (H. Abramson ed. 1967). 
and ten a placebo, and all were sent to a two and a half hour Good Friday service. Of the ten that received the psilocybin nine reported unmistakable features of mystical experience. Of those who had the placebo only one did so, and he to a minor degree. Six months later the two groups could still be distinguished significantly, the experimental group reporting more positive signs of having benefited from the experience than the control group. One of the experimental group, for example, had been seriously thinking of dropping out of school and even of committing suicide before the experiment. He experienced an intense mystical experience and afterward gave up both ideas and finished his work for a degree. $\mathrm{He}$ is now (five years later) serving a clurch.

It is not necessary, however, to study the therapeutic values of religious experience from religious scholars alone. The Second International Conference on the use of LSD in Psychotherapy and Alcoliolism at Amityville, New York, included leading psychotherapists and researchers in the field from North America and Europe. ${ }^{13}$ Again and again in the papers presented at the conference, allusion was made to subjects and patients who liad reported transcendental experiences of a profound nature. For example, Dr. Ruth Fox, Medical Director, National Council on Alcohol, stated:

In this transcendental experience there may be a recognition of 'cosmic consciousness'. Not every patient experiences this complete feeling of 'being at one with the universe'. It seems that the closer one comes to it, however, the more effective and lasting is the change in personality. ${ }^{14}$

Like Dr. Fox, most of these therapists had little or no initial interest in religion as a psychotherapeutic agent until LSD began releasing religious experiences which, not umversally but often, produced amazingly effective therapeutic results.

\section{B. Therapy through Drug Induced Religious Experience}

\section{An Experiment with Alcoholics}

Early researcliers stumbled across the value of religious experience in psychotherapy. The value of ISD in treating alcoliolics was demonstrated imitially by two Canadian psychiatrists, Drs. Humphry Osmond and Abram Hoffer, in connection with provincial health services in Saskatchewan. Relying on its supposed psychotomimetic properties, they had intended to frighten very difficult alcoholics with large doses of ISD. Instead, a great many sustained profound transcendental experiences. In

${ }^{13}$ For the proceedings of this meeting see TrE USE of LSD IN PsycrotaERApY AND AICOHOLISM, supra note 12.

$14 I d$. at 482 . For other similar and pertinent statements on LSD and the mystical see id. at $343,391,419,462-63,482,501-02,561,569-76$. 
an informal report Hoffer stated that five years afterward half the treated group were still abstainers; most of these had had a religious experience..$^{15}$ Hoffer has also summarized eleven studies of LSD use with alcoholics involving a total of 269 cases ${ }^{16}$ with varying dosages and follow-up periods. Of these cases 145 were judged clinically much improved-in effect no drinking-forty-four improved, and eighty unimproved. In a comparison group of eighty alcoholics treated, but without LSD, eleven were much improved, seven improved, and sixty-two unimproved. As a direct result of liysteria concerning the drugs there are now only a few similar projects underway at hospital centers in the United States. One of these is based at the Spring Grove State Hospital in Baltimore, Maryland, where deliberate stimulation of the transcendental experience is used to treat both alcoholism and depression. ${ }^{17}$

Since severe alcoholism is a life and death affair, it would seem that not even the possibility of genetic damage to future generations should hinder science in investigating the uses of psychedelic drugs as treatment. The situation may be illustrated by a middle-aged alcoholic who was referred to me with the mistaken idea that I could admimister LSD as treatment for alcoholism. An educated man, he had lost his skilled position and lad alienated his family and children. No firm would hire him. He had tried psychiatry, Alcoholics Anonymous, and several varieties of cure. He was in despair and was seriously considering suicide. I knew that LSD had improved if not cured cases as serious as his. Although I referred him to one or two research projects, I had little hope that he would be accepted as a volunteer. I could not but wonder in what legal position he would be if he broke the Massachusetts law against the use of hallucinogenic drugs in pursuit of his right to health.

\section{Rehabilitation of Criminals}

LSD has also led to religious experience associated with favorable clinical and rehabilitative results in the field of criminology. In 1961 and 1962, Dr. Timothy Leary, then at Harvard, obtained permission to administer psilocybin to thirty-five inmates at Concord State Reformatory, a maximum security prison in Massachusetts. Recidivism rates were considerably improved, though the results must be considered suggestive rather than definitive, due to the collapse of the project following Dr. Leary's troubles at Harvard.

15 See The USE of LSD IN Psychotherapy 18-19, 114-15 (H. Abramson ed. 1960).

16 Hoffer, A Program for the Treatment of Alcoholism, in THE USE OF LSD IN PSXcEOTHERAPY AND AICOEOLISMr, supra note 12, at 351.

17 Kurland, Unger, and Shaffer, The Psychedelic Procedure in the Treatment of the Alcoholic Patient, in id. at 496-503. 
Somewhat skeptical, I obtained through Dr. Leary an introduction to those subjects still in prison to investigate for myself the depth of their rehigious experiences and to perform a follow-up investigation..$^{18} \mathrm{I}$ concluded that there was no doubt of the notable religious experiences reported by several of the convicts. Those who were serving long terms started a self-directed therapy group within the walls, somewhat modeled on Alcoholics Anonymous. Through the enthusiasm of those who had used the drug, this group spread its influence among many both inside and outside prison walls. Well over a hundred members of the "Self-Development Group," as it is called, have now been released, with recidivism rates considerably better than the general ex-prison population.

One nnember of the original group is a former armed robber who was serving a twenty-year term at the time of the experiment. Aged thirty-six, he had not been beyond the eighth grade and had spent most of his adult life behind bars. His bleak prognosis was reversed through the drug experience. Starting with low doses, he was given $60 \mathrm{mg}$. of psilocybin on the eighth administration. There followed a vision of Christ and a realistic symbolic participation with Christ in some events of the Crucifixion. Shortly after this, he told me, he looked out of the window, "Suddenly all my life came before my eyes, and I said to myself, 'What a waste!" "I have followed his career carefully during the last five years. Information from prison guards and officials have confirmed my impression that the man has been rehabilitated. Recently he was released and offered $\mathrm{a}$ job in the loan business by a former fellow inmate at 300 dollars a week. Being penniless he was tempted, but lie turned it down. "I knew what kind of a loan busmess it was," he told me, "but I knew also that $I$ would lose the inner freedom I secured from my vision if I accepted." The latter has become for him a lind of touchstone or point of reference which stands him in good stead in times of crisis.

Both domestic and foreigu studies ${ }^{19}$ indicate that psychedelic drugs may possibly be a most effective agent for treating the criminal psycliopath-or any psychopath, for that matter. The psychopathic personality is one of the most resistant types of mental disorder-incurable according to some authorities. It reflects both on American bureaucracy as well as on public hysteria concerning the psychedelics that no way has yet been found effectively to study this subject further. ${ }^{20}$

18 For a preliminary account and religious estimate of the results sce Leary and Clark, Religious Implications of Consciousness Expanding Substances, 58 Reurgrous EddCATioN 251-56 (1963).

19 See the account by Dr. Arendsen-Hein in Harroctagondc Drugs and thetr PsycroTHERAPEUTIC USE 101-06 (R. Crocket, R. Sandison, \& A. Walk eds. 1963) (14 of 21 criminal psychopaths reported as clinically improved).

20 I have secured permission from Commissioner John A. Gavin of the Massachusetts 


\section{The Use of LSD in Treating Pain}

Officials have, however, been more cooperative in authorizing the use of LSD to alleviate pain. Several years ago Dr. Eric Kast, at the University of Chicago Medical School, administered LSD to 128 patients suffering from cancer estimated to be terminal in one to two months. ${ }^{21}$ Relief from pain was striking during the first twenty-four hours after administration; and there still remained some effective relief from intolerable pain twenty-one days later. In his reports Kast does not comment on the religious factor directly though it is implied in his statements concerning new and more wholesome attitudes toward death. This work is being followed up at the present time at Spring Grove State Hospital, Baltimore, Maryland. But it is still surprising that experimentation of such promising and humane nature is not more widespread.

\section{Psychedelic Drug Use by Religious Institutions}

If, as I have demonstrated, one of the consequences of ingesting psychedelic drugs is religious experience, one might expect their use by religious institutions. This has in fact been the case throughout history both in this country and elsewhere.

\section{The Ancients}

In Ancient Greece the Eleusinian Mysteries required the drinking of a secret potion as part of the initiation ordeal, and Plato made guarded reference to a drug nucl like LSD in The Lawes. ${ }^{22}$ There is also good evidence that in ancient times the Indian inhabitants of Latin America sucl as the Aztecs used psychedelic mushrooms. In Mexico's back country ceremomies are still carried out by local priests utilizing sucli mushrooms. ${ }^{23}$

\section{The Native American Church}

In the United States the Native American Cluurch makes religious use of the psychedelics in its sacramental ceremomes. This church is a loosely organized association of some 250,000 American Indians representing a number of the principal American tribes. The drug used is

Department of Correction to draw up a research plan using appropriate volunteers from the state prison system to test the value of psychedehc substances in rehabilitation. However, red tape and legitimate fears concerning possible chromosomal damage have so far prevented any approach to the National Institute of Mental Health or other governmental agencies, the only present legal source of most of these drugs.

21 Kast, Pain and LSD-25: A Theory of Attenuation of Anticipation, in LSD: THE Consciodsness-Expandng Drog (D. Solomon ed. 1964); Kast, The Measurement of Pain: A New Approach to an Old Problem, 2 J. New Drugs 344 (1962).

22 See Wasson, The Hallucinogenic Fungi of Mexico, 1 Psychedencic Review 43-46 (1965).

23 See id, at $27-42$. 
mescaline from the mescal button on the cactus plant, in its raw form called peyote, whicl is dried and then clewed or brewed as a bitter tea. ${ }^{24}$ The practice and the cult have been traced back for nearly a hundred years and have doubtless existed in some form for many centuries. The cult is a syncretistic one combinimg both Christian and Indian elements, and peyote use has been a bone of contention not only between the peyotists and certain Christian missionaries but also withm the Indian tribes themselves.

Most of the strictures heard in our society against LSD-such as that it drives people crazy, debases their morals, and leads to miscellaneous vices-can also be heard froin Indians themselves. Further, the restrictive laws and regulations of white A.merica have had their counterparts among the Indians. Finally, Indian agents and missionaries, zealous to protect the Indians from what they consider a debilitating and pagan influence, have harassed the peyote cults. Some of the regulations have succeeded in part, but apparently they never have been strictly obeyed. Detracters have always been handicapped by the inability to produce hard evidence of harm done by peyote. In fact, the weight of the evidence indicates that peyotists have reduced their tendencies to drunkenness, have lived more responsible family hives, and have become reliable members of their communities. ${ }^{25}$

For inany years the peyote cults, in their contacts with white missionaries and Indian agents have had their ups and downs. The Indians' chief white supporters have been scholars whose interests have been relatively dispassionate. They have reported the positive aspects of peyote religion and so refuted the thought that because peyote is a drug and strange to white people its use in worship must be a debilitating and immoral practice. In fact, white scientists' favorable testimony has led to a trend of recent judicial decisions supporting the Indians' right to use peyote sacramentally against federal, state, and even Indian tribal laws. $^{26}$

\section{The League for Spiritual Discovery and the Church of the Awakening}

Based partly on the understandable theory that what is permitted to Indians should be permitted to other citizens too, and partly on the undoubted evidence, as set forth in this Article, that psychedelic drugs

24 See D. Aberte, The Peyote Retigion among: the Navaho (1966); W. La Barre, The Peyote Cutt (1959); J. Srotkin, The Peyote Relicion (1956).

25 See J. SxorkIN, supra note 24, at 48-77; D. AlierLE, sulpra note 24 at 354.

26 For discussion of the legal status of psychedelic drugs, including the use of peyote by the Native American Church, through 1963, see Barrigar, The Regulation of Psychedelic Drugs, 1 PsYchedeIIC REVIEW 394-441 (1964). For a theoretical discussion in the same issue, see Bates, Psychedelics and the Law, id. at 379-92. 
release religious experience, several groups of whites have incorporated their own cultic use of the psychedelics. Perliaps the most visible of these is the League for Spiritual Discovery founded by Dr. Timothy Leary, incorporated as a religious institution in the State of New York with headquarters at Millbrook, New York. The organization does not insist on the use of drugs. A recent midnight raid on their headquarters turned up only a sniall quantity of marijuana in one guest's possession.

Probably the most conservative and careful of many such institutions in the United States is the Church of the Awakeming, incorporated in New Mexico with headquarters at Socorro, New Mexico. It was founded by two retired plyysicians, Drs. John and Louisa Aiken, who ceased their practice in order to embark on a personal search for the spiritual meaning of life and to encourage others to do the same. The psychedelic drugs are regarded not as the sole means of pursuing a religious life but siniply as one auxiliary whicli, when properly used, may aid in the quest. As licensed plrysicians the Aikens have been entitled to administer mescaline and peyote, though the present, more dubious status of these drugs has led them to be more cautious in recent years. In the past they have administered both mescaline and peyote under sacramental conditions after several preparatory and screeming sessions. Recently the Food and Drug Administration refused a request by the Church of the Awakening for permission to use peyote, as does the Native American Churcln, in sacramental ceremonies. The Church of the Awakening is now considering whether to make a test case of its right to use psychedelic drugs under the Constitutional guarantee of freedom of religion.

\section{IV}

PSYCHEDELIC DRUGS AND THE LAW

Law enforcenent agents tend to assume that the psychedelic drugs can be dangerous and that therefore no individual or group niay be allowed to use then. Conceivably an irresponsible group might forn a churcli as a cloak for engaging in activities harmful to the public. However, the experience encountered through drugs is usually so awesonie, and the total process requires so much of those in attendance, that the cereniony is not apt to be pursued except by the earnest. In addition, lrowever much religiously minded people may pioneer and innovate in a way that is slocking to the conventional religious mind, as soon as institutionalization of a new idea begins, conservatism begins to assert itself. This clraracteristic is much more effective than the law in keeping dangerous religious tendencies under control. Consequently, granting permission to religious groups to use psychedelic drugs may in the long run be the most effective method of minimizing the dangers of drugs. 
Finally, whatever the conventions of the law may be, the disinterested citizen's common sense attitude might be that the law has no right to assume that a given religious institution would abuse its right to use the drugs. The wiser course might seem to be to wait until irresponsibility has been demonstrated before imposing sanctions. Even then it ought to be demonstrated that more harm than good has been caused by the right to use the drugs.

In its most profound and essential aspects, the mystical consciousness which can be released by the psychedelic drugs is like nothing before experienced. In a study of LSD's religious effects, eight normal volunteers were given low to moderate doses daily for a period of four to sixteen days. They were asked to rate their experiences on a number of parameters of mystical experience such as unity, timelessness, blessedness and peace, experience of God and the Holy, the feeling of death and rebirth, and the subjective sense of the significance of the experience, compared to their usual everyday experiences. They could designate six different levels of intensity, ranging from "no different from everyday life" to "beyond anything ever experienced or imagined." Of 160 ratings only seventeen were rated "no different from everyclay life," while fifty-two were rated "beyond anything experienced or imagined." This was about one and two-thirds greater than the next most used category two grades below, "markedly and intensely above normal."27

This study lends empirical confirmation to the mystical feeling that it is impossible to describe the experience to those who have not participated in similar experiences. It also further supports my point that prosecuting religiously motivated individuals who violate drug laws ironically forces violators to conduct their defenses before those who, no matter how well intentioned and experienced in the law, are nevertheless unable to appreciate the defendant's religious experiences. This is not to say that all ingesters of the psychedehic drugs are responsible citizens. But at least some will bear comparison witl Socrates, Meister Eckhart, and Francis of Assisi in their apprehension of truth, their compassionate concern for mankind, and their willingness to hold to their vision in the face of threats of imprisonment and extreme punishment.

It is one of the tragedies of our time that dispassionate evaluation of the psychedelic drugs-their values and their dangers too-has been made so difficult, partly by the inability of even the educated mind to tolerate the intrusion of new methods and experiences on their accustomed

27 These figures are from a study carried out by the Worcester Foundation for Experimental Biology under a Public Health Grant and reported in a paper by W. Clark and M. Raskin read at the American Psychological Association Meeting, Washington, D.C., Sept. 4, 1967. 
comfortable thought patterns. So far, the voices most influential in swaying public attitudes toward the drugs and their users have been eminent medical men, mostly well-meaning psychiatrists acquainted only with the deleterious effects of drugs. What if the only information the public had about automobiles came from ambulance drivers! Quite contrary to public assumptions, the true experts are those who have had experience in carefully supervising a wide sampling of volunteer drug users. Since the important subjective dimension will always be missing for those who limit themselves simply to objective observation, the truly conscientious expert will be as willing to experiment on himself as he will be to subject others to the influence of the drugs.

From personal experience with both pseudo-experts and experts so defined, I can testify that the latter are much more impressed by the positive possibilities of drug use, anxious for further research, and openminded on their possible use in effecting creative changes in artistic, religious, psychotherapeutic, and even educational spheres. No responsible person wants to see these powerful substances used without control, not even those drug users whom society has remanded to the irresponsible category. The question for everyone is not whether, but how to regulate them. Because psychedehic substances are so prevalent and circumvention of the law so easy, laws alone cannot effect this control.

Lawmakers must, of course, be guided not only by scientific findings but also by knowledge of all facets of psychedelics. Their nost subtle and puzzling aspect is their rehigious agency. As a psychologist of rehgion, I have been impressed by the fact that psychedelic drugs, handled correctly, appear to offer incomparable opportumities for studying religious experience. Religious experience is the most profound and powerful aspect of the human personality and is the aspect most capable of bringing out the compassionate and creative qualities of the human spirit. Furthermore it is the most effective agent of wholesome, profound personality change. The law can maximize or minimize the value of the drugs for religion. It can also make the mistake of persecuting men who are merely attempting to experience that part of their nature that they feel most entitles them to regard themselves as human, namely their encounter with Ultimate Reality, or what they call God.

In pursuit of sucli encounter, religious people have felt compelled to defy the law when lawmakers have misunderstood the offenders' basic urge. Education, cominon intelligence, and judgment alone are therefore not enough in dealing with the problems of psychedelics. Men will require wisdom to cast off the chains that fetter them in the dark Cave of Illusion to encounter the sunlight which, for Plato, must enlighten those few fit to judge and govern the State. 